\title{
Does social media transform city government? A case study of three ASEAN cities
}

\section{Bandung, Indonesia, Iligan, Philippines and Pukhet, Thailand}

Sataporn Roengtam

Department of Public Administration, Faculty of Humanities and Social Sciences, Khon Kaen University, Khon Kaen, Thailand

\section{Achmad Nurmandi}

Department of Government Affairs and Administration, Jusuf Kalla School of Government, Universitas Muhammadiyah Yogyakarta, Yogyakarta, Indonesia

David N. Almarez

Department of Political Science, Iligan Institute of Technology, Mindanaou State University, Iligan, The Philippines, and

\section{Anwar Kholid}

Department of Government Affairs and Administration, Jusuf Kalla School of Government, Universitas Muhammadiyah Yogyakarta, Yogyakarta, Indonesia
Case study of three ASEAN cities

Received 21 December 2016 Revised 28 March 2017 14 April 2017 Accepted 18 April 2017

\begin{abstract}
Purpose - This research aims to investigate the impact of the use of social media on the organizational form and function in selected local governments of Indonesia, Thailand and the Philippines.

Design/methodology/approach - This research used quantitative and qualitative methods. The researchers not only conducted comparative- explanatory studies among the three ASEAN cities but also used multiple-informant and secondary data analyses. All variables are operationalized into indicators and transformed into a questionnaire in three languages: English, Indonesian and Thai. Primary data for the research were collected using a cross-sectional survey conducted in Bandung City, Indonesia; Iligan City, the Philippines; and Pukhet City, Thailand.
\end{abstract}

(C) Sataporn Roengtam, Achmad Nurmandi, David N. Almarez and Anwar Kholid. Published by Emerald Publishing Limited. This article is published under the Creative Commons Attribution (CC BY 4.0) licence. Anyone may reproduce, distribute, translate and create derivative works of this article (for both commercial and non-commercial purposes), subject to full attribution to the original publication and authors. The full terms of this licence may be seen at http://creativecommons.org/ licences/by/4.0/legalcode

The authors cordially thank two blinded reviewers who have contributed to improve the quality of this paper. Authors also want to thank Jusuf Kalla School of Government Universitas Muhammadiyah Yogyakarta and Thailand government that supported this research.This research is a joint research project under Jusuf Kalla School of Government funding, Khon Kaen University research project and Iligan Institute of Technology, MSU research project.

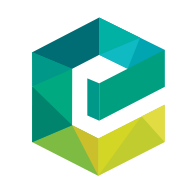

Transforming Government: People, Process and Policy Vol. 11 No. 3, 2017

pp. $343-376$ Emerald Publishing Limited
1750-6166 DOI 10.1108/TG-10-2016-0071 
Findings - This research found that social media use has not yet affected the internal organizational processes in the three cities. Also, social media use is not appropriated as a space for citizen-government interaction. It is used for only information dissemination to the public; social media seems to have been used for only collecting information from citizens but not for involving them in the decision-making process.

Research limitations/implications - This research covers only three cities in the ASEAN countries, and the findings cannot be generalized to others. Moreover, this research looks at the supply-side dimension or government organization side only. However, the findings confirm that findings of previous research studies that social media use in the local government is only for information dissemination.

Practical implications - Legal bases for social media use could be an urgent matter to address to advance more fundamental changes in government processes.

Originality/value - There is no prior comparative study on the use of social media by local governments in the ASEAN countries. Social media owing to its sense of personalization or sense of community improves communication between citizens and government better than e-government sites; however, as articulated by Mirchandani et al. (2008), social media may hinder rather than facilitate the delivery of services (Mirchandani et al.,2008). This is due to the absence of a legal basis of its use, as well as agreements on the manner of its use, which prevents full integration of social media into the governance process, particularly in the cases of the cities of Iligan, the Philippines, and Phuket, Thailand.

Keywords Communication, Transformation, Social media use, Cultural change, Membership

Paper type Research paper

\section{Introduction}

The growing use of social media in government and the interaction between citizens and government via the government website encourage change in internal government bureaucracy. Citizen participation in governance through the broad space of social media for public participation ensures accountability. Social media is "a group of Internet-based applications that build on the ideological and technological foundations of Web 2.0, and that allow the creation and exchange of User Generated Content" (Kaplain and Haelein, 2010). "Web 2.0" refers to internet platforms that allow interactive participation by users. "Usergenerated content" refers to the ways in which people may use social media. The Organization for Economic Cooperation and Development (OECD) specifies three criteria for content to be classified as "user-generated":

- it should be available on a publicly accessible website or on a social networking site that is available to a select group;

- it should entail a minimum amount of creative effort; and

- it should be "created outside of professional routines and practices" (OECD, Participative Web and User-Created Content: Web 2.0, Wikis, and Social Networking18 (2007) [hereinafter OECD Report] (Kaplain and Haelein, 2010, p. 61).

Figenschou (2015) noted in recent scholarship on media-government negotiation that in the wake of intensified media pressure and critical news stories featuring failed policies, dysfunctional systems and incompetent civil servants (Deacon, 2001; Gordon, 2000; Schillemans, 2012), governments have had little choice but to adapt to and even adopt a media logic. The theory of mediatization emphasizes how the news media influences other political elites and institutions, in defining the constitutive rules of communication (Terwiesch et al., 2002; Altheide, 2004; Mazzoleni and Schulz, 2010; Strömbäck, 2011). Lazer et al. (2009), found that digital government data need to be analyzed and interpreted to understand to what extent they support the government's mission. There is no prior study on social media use by local governments in the ASEAN countries. Many agencies are however reluctant to measure their online interactions, or are even prevented by their 
interpretation of existing laws and regulations (Mergel, 2013). Social media, because of its sense of personalization or sense of community, improves communication between citizens and government better than e-government sites; however, as articulated by Mirchandani $e t$ al. (2008), social media may hinder rather than facilitate the delivery of services. In South Korea, social media connections have a considerable influence on citizen engagement via Twitter that serves as a source of public information on important topics such as safety and health, but the government's efforts are less effective in communicating with the citizens and in responding to their needs (Khan et al., 2014).

The application of information and communication technology (ICT) has profound organizational challenges to government agencies, especially in two crucial respects:

(1) restructuring of administrative functions and processes; and

(2) coordination and cooperation between different departments and different levels of government (Aichholzer and Schmutzer, 2000).

However, many e-governments projects, in both developing and developed countries, are not always examples of success stories. Chadwick (2011) found that the failure of "TechCounty", an online citizen project in the USA, was due to institutional variables such as: the e-government team was free-floating rather than embedded in the county executives' office and was therefore unable to drive change; departmental rivalry and different decisionmaking cultures; ambivalence on the part of elected representatives; technologically aware leadership was lacking; and an eagerness to avoid bad publicity. Other researchers call for the concept of transformation in using ICTs, including social media for government (Klievink and Janssen, 2009). They conclude that transformation is a complex problem to which no universal approach exists and for which different types of models can be used (Klievink and Janssen, 2009). Managers want models that help them realize the transformation, whereas policymakers are more interested in models that help them shape the right direction and identify relevant elements (Klievink and Janssen, 2009).

Meanwhile, there are fewer studies on the relationship between technology and organizational form and function. Between 1996 and 2005, only 2.8 per cent of 1,187 researchers published in four leading journals focused on the relationship between technology and organizational form and function (Zammuto et al., 1999). In their research article, Zammuto et al. (1999) concluded that it is very important to study how information in the social and organizational sense is generated because organizing takes place around those understandings and subsequent actions, not only around information acquisition and transmission but also on the study on how affordances emerge and evolve with changing technological and organizational features (Malhotra et al., 2007), and to understand the impact of affordances on boundary conditions. Zammuto et al. (1999) use the term affordance that refers to affordances for organizing that depend not only on the functionality characterizing the information technology but also on the expertise, organizational processes and procedures, controls, boundary-spanning approaches and other social capacities present in the organization.

With the advent of social media and its growing impact on how people do things and how they interact, it is interesting to find if the same has made inroads into local governance. The challenge is to find the pattern and the level of use of social media in local governance and if social media has made it easier for local government functionaries to communicate in terms of information gathering for decision-making, as well as in disseminating information to the public and in receiving feedbacks. This research investigates the impact of using social media on organizational form and function of selected local governments in Indonesia, Thailand and the Philippines. What is the current level of social media use in three cities of ASEAN, namely, 
Bandung, Indonesia; Pukhet, Thailand; and Iligan, the Philippines? What are the challenges to the internal capabilities of the local government agencies of Indonesia, the Philippines and Thailand in using social media and its contribution to policy-making?

This research proposes that those methods cannot be only applied but there shall be other ones applied also. So, this research attempts to propose that there is other ways to effect a change. Another approach can be used to reinforce other participatory methods quite well. Owing to the benefit of social media, this research will study the impact of social media on structural changes of the local government. This research would like to study, after using social media, whether the structure has changed, how and why.

The searcher expected that will find out some concrete results that can be displayed the significant impact of social media to local government which will be useful for developing strategies to promote citizen engagement to be more successful. In terms of academic contribution, the results will be able to propose basic knowledge on social media use in public administration, especially at the local level. This knowledge can be used to construct concepts and theories in local governance which is a current issue in the study of public administration policies.

In terms of social contribution, the results will be able to propose approaches used by the local government development, especially for effecting structural change. The results will indicate the major issues that the local government needs to impove upon so as to adjust itself to match with administrations of its counterparts in the more complex society today. The results will guide some approaches for change when it has to work with the new environment which will be happened rapidly. So, this research will help the local government learn about how to work together with people in the future.

\section{Theoretical review}

\subsection{Social government and organizational transformation}

Oginni (2015) said that the development of social media tools over the past decade has altered modes of communications between governments and citizens. Social media has opened ways for greater political participation, thereby creating new social dynamics. It is an internet-based tool that unifies geographically dispersed individuals on virtual platforms through user-generated content. Leavey (2013) defines social media as a social structure made of nodes, comprising individuals or organizations tied by one or more specific types of interdependencies, such as values, ideas, financial exchange, friendship, kinship, dislike, conflict or trade. In reality, the innovative tool brings together people of common value systems, visions and aspirations to collaboratively form opinions on issues of concerns in virtually connected environments. Pinzón (2013) posits that social media is part of a wider trend in a communication landscape that is characterized by mass collaboration; it is responsible for a significant portion of time expended online. In the context of this study, social media refers to online tools that permit real-time interaction and feedback (for instance, Web 2.0); it is a broad term that extends beyond Facebook, Twitter and LinkedIn to include e-government.

Social media can also be seen as a productive tool that relives social struggle and policymaking. The concept of public policy was developed in response to heightened social struggle and duties of governments to ensure citizens' welfare (Nyong'o, 1998). Public policy is concerned with how societal issues are defined, constructed and approached on a political level, and it is used to examine the effects of a government's actions or inactions. Although the inclusion of inaction may seem counter-intuitive, public policy encompasses all aspects of a government's decision-making process (Mergel, 2013; Simon et al., 2015). Social media can transform government organization into a social government (s-government). This 
transformation results from the capability of social media to enable organizational change, which requires the management of projects or programs to develop or integrate systems, leadership and change in culture or organizational factor (Klievink and Janssen, 2009; Kavanaugh et al., 2012, Johannessen et al., 2016). However, based on some previous studies, social media use could influence position or membership of a government employee (legal issue), an organization, a culture, a communication and then the decision-making process (Linder and Nicole, 2012;Kavanaugh et al., 2012; Khan et al., 2014) (Table I).

Case study of three ASEAN cities

\subsection{Organizational factor}

A government organization is a unit of the social system that is strongly affected by it. In a social system, organizations conduct experiments that concur with our everyday experience with them (Achterbergh and Vrients, 2009). According to Luhmann, an organization belongs to the class of an autopoietic system as a result of decisions and function, as a decision premises for follow-up decisions (Achterbergh and Vrients, 2009). Furthermore, Luhmann argued that viewing organizations as merely consist merely of goals and/or means to realize them is to mistake results of organizing for organizing itself (Achterbergh and Vrients, 2009). The theory of autopoiesis was developed by two Chilean cognitive biologists Humberto Maturana and Francisco Varela in the 1960s and early 1970s. Abstracting from life, autopoiesis is defined as a general form of system-building using self-referential closure. We would have to admit that there are non-living autopoietic systems, different modes of autopoietic reproduction and general principles of autopoietic organization which materialize as life, and also in other modes of circularity and self-reproduction. In other words, if we find non-living autopoietic systems in our world, only then will we need a truly general theory of autopoiesis which carefully avoids references that hold true for only living systems (Luhmann, 1986, p. 172). The basic building block of social systems is communication. Communication consists of information, utterance and understanding, and it allows for a system's self-constitution. Luhmann defines social systems as being principally boundary-maintaining systems (Hernes and Bakken, 2003). Luhmann conceives of communication as a combination of three components: information, utterance and understanding, each of which Luhmann conceptualised as selection.

Information is a selection from a repertoire of possibilities. Every communication selects what is being communicated from everything that could have been communicated. Utterance refers to the form of and reason for a communication (Luhmann, 2003) or how and why something is being said. It is the selection of a particular form and reason from all possible forms and reasons. Understanding is the distinction between information and utterance (Seidl, 2004; Karantzeni and Gouscos, 2013).

Communications that communicate a selection as a selection include elements of organizations (Achterbergh and Vrients, 2009). Communication has an inner structure as a selection of a set of selectable options, and it can be recognized as a decision and as being connected to prior decisions and thereby contribute to the self-production of the organization (Luhmann, 2000). An organization needs a structure to support the production of elements by elements, namely, decision premises. Decision premises involves three aspects: normative points of reference, providing a focus for the production of follow-up decisions; decision premises, contributing to the regulation of the production of decisions by marking decisions from them; and a new decision takes into account existing decision premises as presuppositions (Achterbergh and Vrients, 2009).

\subsection{Membership}

How do decision premises work in an organization? There are nine types of decision premises, namely,: membership, communication pathway, decision programs, personnel, 
TG
11,3

348

Table I.

Literature review on the relationship between social media use and organization transformation in government

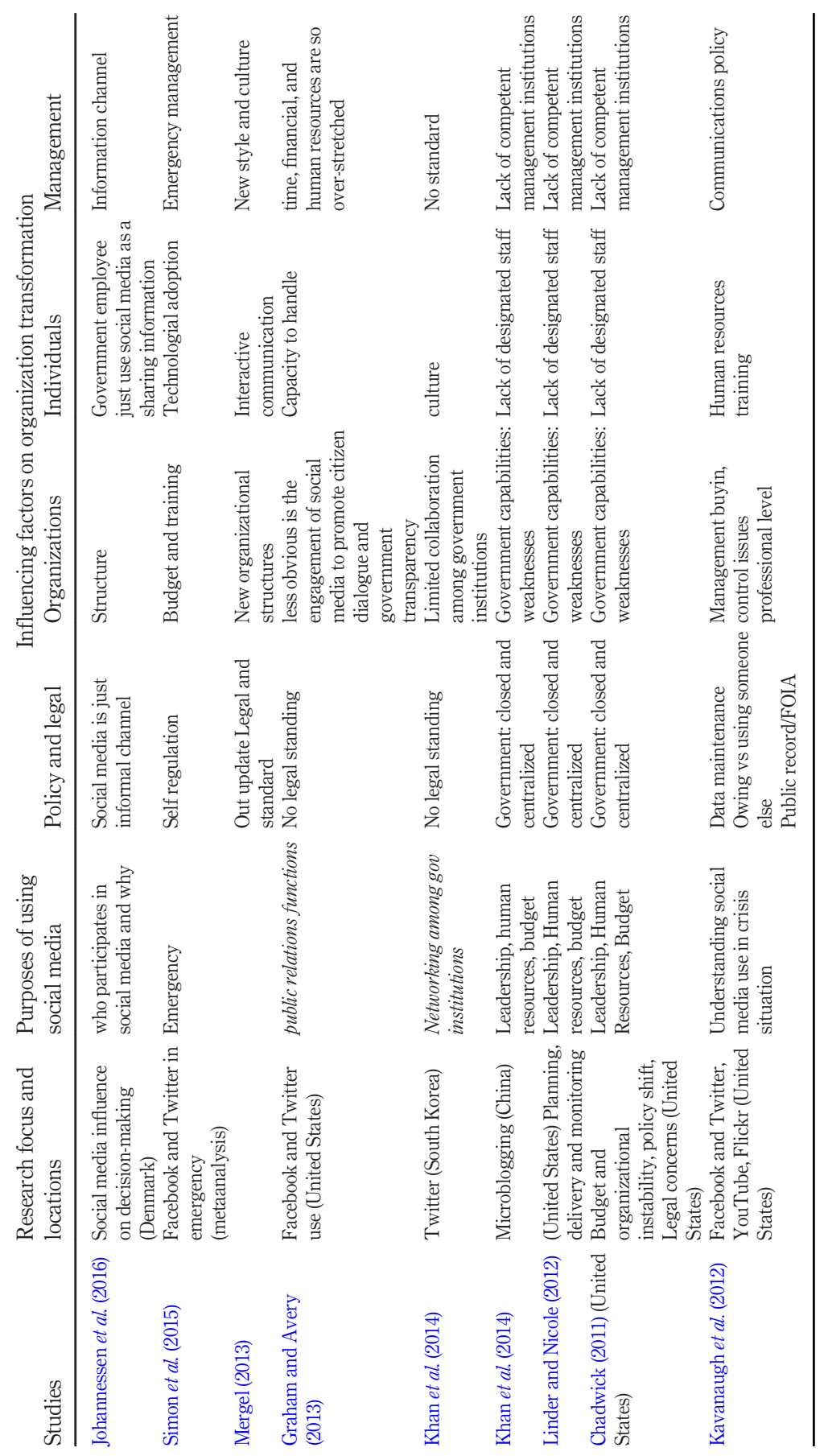


positions, planning, self-description, organizational culture and cognitive routine (Achterbergh and Vrients, 2009). In an organization, only members can contribute to the generation of decisions. However, using social media, citizens influence direction and outcomes of the government, improve the government's situational awareness and may even help execute government services on a day-to-day basis (Linder and Nicole, 2012). In other words, citizens are members of government organization who can contribute to the generation of government decision on a day-to-day basis. Governments' transition from Web 1.0 to Web 2.0 will require fundamental organizational and administrative changes, as three ASEAN cities many of the emerging social-collaborative technologies sit uncomfortably with public sector hierarchies and decision-making processes (McNutt, 2014), and social networking government (Panagiotopoulos et al., 2011). The social-collaborative technology is a valuable tool for identifying the main issues perceived by citizens with respect to a particular social problem or domain of government activity and for collecting from the citizens interesting ideas on possible solutions and directions of government activity (i.e. for applying crowdsourcing ideas in the public sector) (Spiliotopoulou et al., 2014).

\subsection{Organizational culture and cognitive routine}

Like other organization scholars, Luhmann (2006) argues that organization has undecided decision premises, namely, organizational culture and cognitive routine. Organizational culture has basic values woven into the fabric of the organization, as well as undecided rules for decent behavior or for the attribution of blame or praise, which are also examples of cultural decision premises (Achterbergh and Vrients, 2009). Cognitive routines are a byproduct of ongoing practices in the organization's relation to its social and non-social environments. One character of the government is a joined-up or integrated government service delivery; governments have to deal with the problem of fragmentation within the constitutional, legal and jurisdictional limits (Scholl et al., 2012). Today, the most significant barriers to social media adoption are organizational, cultural and legal - not technological (McNutt, 2014). Government organizations should be willing to investigate whether more playful interactions with citizens can help to engage on serious issues (Meijer et al., 2012). The application of social media methods will not lead automatically to better and more socially rooted and responsive public policies, if it is not combined with a change of culture of public servants and politicians (Spiliotopoulou et al., 2014).

\subsection{Communication and organizational structure}

The second type of decision premise is a communication pathway, prescribing the "route" that should be followed in operations, to be counted as decision in an organization (Achterbergh and Vrients, 2009). Luhmann (2000) argued that the communication pathway does not necesarily involve "hierarchy, but also a lateral communication one". Luhmann's (2005) fundamental idea was that organizations decide by themselves what is considered as a decision. This applies to decision communication as well. Personnel and position in public administration are organizational structuring variables (Weerakkody, 2009). Luhmann argues that competencies and experiences are very important for decision premises. Luhmann (2005) also states that the nature of decision communication changes when the time to make a decision occurs. If decision communication is seen as communication, which leads to a decision, then the post-decisional information of decision communication differs from pre-decisional communication. Communication mediated by ICT (or social media) provides a virtual platform for an informal and open sharing of thoughts, expectations, assumptions and values which offers an opportunity to form alliances of collective responsibility, which may be different from the formal hierarchies of management relationships within the parent organization (Mezgar, 2006). 
TG

11,3

Another research recommended that government organization should implement its networking strategy by mobilizing Twitter accounts of various government institutions and promoting their cooperation instead of following Twitter accounts of citizens or networking with them (Khan et al., 2014). In other words, Klievink and Janssen (2009) proposed the integration of ICT into government organization. Integration in government can be defined as the "forming of a larger unit of government entities, temporary or permanent, for the purpose of merging processes and/or sharing information” (Scholl et al., 2012). Hence, integration extends to both process integration and information integration (sharing) (Klischewski, 2004) and pertains to the institutional dimension and in part to the high-level functional dimension (Kubicek et al., 2009; Tsohou et al., 2014).

In other words, as opposed to interoperation or interoperability, which alludes to the technical and lower-level functional aspects, integration refers to the non-technical and governance aspects of intra- and inter-government collaboration. Further, following Scholl and Klischewski's set of definitions, interoperation "occurs whenever independent or heterogeneous information systems or their components controlled by different jurisdictions/administrations or by external partners smoothly and effectively work together in a predefined and agreed upon fashion" (Scholl et al., 2012), whereas interoperability "is the technical capability for eGovernment interoperation" (Scholl et al., 2012). In a functional perspective, IT-based interoperation encompasses layers such as technical (signal-level) interoperation, syntactic (data-level) interoperation, semantic (information/meaning-level) interoperation and finally business process interoperation (Kubicek et al., 2009). Others propose to distinguish further between technology (computer), business process, information, values and goals when analyzing government integration and interoperation projects (Gottschalk, 2009).

\subsection{Personnel and position}

Personnel and position in public administration are organizational structuring variables (Weerakkody, 2009). Luhmann (2005) argues that competencies and experience are very important for decision premises, and he also states that the nature of decision communication changes when the time to make a decision occurs. If decision communication is seen as communication, which leads to a decision, then the post-decisional information of decision communication differs from pre-decisional communication. Communication mediated by ICT (or social media) provides a virtual platform for an informal and open sharing of thoughts, expectations, assumptions and values which offers an opportunity to form alliances of collective responsibility which may be different from the formal hierarchies of management relationships within the parent organization (Mezgar, 2006). Information factors consist of communications and information technology (Kavanaugh et al., 2012). Those aspects are important variables regarding the relationship between government organization and citizen used to study Arlington County. The influence of ICT use on organization transformation process in The Netherlands confirms the aforementioned findings (Klievink and Janssen, 2009). However, bureaucratic behaviors are also undeniably linked to the culture and structure of the organization within which they work, and the managers from whom they receive direction (Fulla and Welch, 2002). Moreover, the relationship between citizen and bureaucrat continues to be based on public service. As a result, any model of interaction between citizen and government must explicitly include the broader social contexts from which they originate. Fulla and Welch (2002) furthermore expect that the organization can choose among five options for response to an asynchronous query: non-response, generic response, direct informational response, referred informational response and referred action.

Meanwhile, the response level is dependent on the performance of the virtual team in a certain organization, and the link between the virtual team members is more social and 
psychological in nature (Mezgar, 2006). The virtual teams function on trust rather than control (Handy in Mezgar, 2006) which requires lateral communication and active involvement from each individual under a flat organizational structure, participatory management practices and novel schemes of shared responsibility (Mezgar, 2006). The Luhmannian perspective developed here helps us to address the relatively neglected questions of how the operating and strategy routines of an organization are related to each other, and how both are related to the generation of strategic change (Hendry and Seidl, 2003). Social systems for Luhmann are not, therefore, systems of action, structured in terms of the thoughts and behaviours of individual actors, but these are systems of communications in which communication determines what further communication occurs. Luhmann introduces his concept of episode in the context of societal change, and it does not feature explicitly in his accounts of organizations.

From a social systems perspective, the routine suspension of normal operating structures is essential for the long-term survival of an organization and an integral part of its structure. The second insight is that strategic episodes are important for not only changing strategies but also confirming and reinforcing them. The third insight, which again challenges the exceptionalist view, is that for the line management of an organization, strategic episodes are the routine focus of strategic practice. The fourth insight concerns the relationship between organizational strategy and the practices of "strategists". Government organizational culture in the emerging "digital era governance" (DEG) and "transformational government" (t-gov) paradigms is such that "citizens and businesses will increasingly co-produce most individual outputs using electronic processes, leaving agencies to provide only a facilitating framework" (Dunleavy et al., 2005) and "citizen empowerment” (CS Transform, 2010; Waller and Genius, 2015).

\subsection{Public policy-making}

Luhmann (2005) emphasizes that decision communications are not produced by human beings but by the social system, or by the organization. Luhmann sees decisions as the elements of an organization and "compact communications", which communicate their own contingency. Luhmann (2005) also theorizes that decision communication is the only form of communication that contributes to the autopoiesis of an organization. Decision programs are regulative conditions for correct or incorrect decision behavior, namely, goal program and conditional program (Achterbergh and Vrients, 2009). Goal programs specify goals (desired) that should be pursued, depending on the circumtances or expected side effect, and conditional programs have a general form that allows for different levels of specification (Achterbergh and Vrients, 2009).

When government managers face the growing demand from netizens via social media, they are not producing sequential decisions, or one decision after the other, but they can produce multiple coherent decisions at the same moment in time and at different moments in time (Achterbergh and Vrients, 2009). Luhmann defines those decisions as planning. However, organizations have other means of integrating decision premises, namely, selfdescription. Self-description function is a means to unify the multitude of decision premises (Achterbergh and Vrients, 2009). IT was primarily used to automate existing operations and to increase the speed of communication. Automation within organizational functions meant that routine information collection and storage tasks were taken over by IT, replacing paper and people with electrons, without fundamentally changing the way work was done as "automated plumbing" (Zammuto et al., 1999). This means organizations are not "sequential mechanisms" producing one decision after the other, but at the same time organizations must coordinate "event-like" (via social media) character of decision, called planning (Luhmann, 2006; Achterbergh and Vrients, 2009). Organizations have to decide what to observe in the environment, how to observe it and which conclusions to draw from their 
TG

11,3

observations (Kieser and Leiner, 2009). Decisions are the basic elements of organizations. When making decisions, managers refer to earlier decisions, including decisions on how to observe and interpret the environment, and thus establish self-referentiality (Seidl, 2004).

In each stage of policy processes, technology has an important role to play in the digital age. The policy process requires quality inputs, decision-making and feedback mechanisms to be successful. One important quality of enhanced policy is wide participation in the policy process. Social media thereby presents an opportunity to incorporate a multitude of opinions or alternatives during policy processes. Citizen engagement is crucial in directing policy to the most pertinent issues within the receiving locality (Imurana et al., 2014).

A recent study on online activity in social media for public policy, social and political issues of some selected countries reveals that developing countries seem to have the highest proportion of engagement in online public policy and social and political issues (IpsosMarkinor, 2012; Sáez-Martín et al., 2014). The argument was based on the assertion that the democratic history and experience of a country plays a role in the magnitude of online engagements and extent of social media use as "business models" for the development of an e-government (Beynon-Davies, 2007). That is, a grown-up democratic country tends to have a more organized system of channels for citizens to air their views than emerging economies. At each stage of the public policy process, factors such as social distance between policymakers and the general public, information asymmetry, politicization of policy implementation and weakened feedback mechanisms have been identified as challenges to public policy processes in Africa (Imurana et al., 2014). However, in terms of citizen influence, social media did not provide a well-functioning public sphere in policymaking or just one of many channels where low-power stakeholders attempted to reach out (Johannessen et al., 2016).

\section{Research method}

ASEAN, while diverse, can be clustered into three groups by internet penetration rates: Cluster 1 (above 60 per cent): Singapore, Brunei and Malaysia; Cluster 2 (25-50 per cent): Indonesia, Thailand, the Philippines and Vietnam; and Cluster 3 (1-20 per cent): Cambodia, Lao PDR and Myanmar (Internet Society, 2016). We intended to study only the middle status or Cluster 2 (based on internet penetration) owing to the lack of research in these countries, namely, Indonesia, Thailand and the Phillipines. Then after selecting Indonesia, Thailand and the Phillipines, we purposively selected three cities in ASEAN countries, namely, Bandung, Indonesia; Iligan, the Philippines; and Pukhet, Thailand, based on the current status of social media use in their respective city governments both by citizen and government. Bandung whose population is 2.3 million (42 per cent citizen using social media) is considered as a best case study city because it has quickly adopted social networking sites and the use of Twitter (Nurmandi, 2015). In Iligan City, the Philippines, whose population is 3,42,618 (50.32 per cent using social media), this is done through the city's Facebook account - @LGUIliganCity (www. gov.ph/laginghanda/socmeddirectory/). Facebook, in particular, affords users a high degree of social presence, making it the best tool for creating and nurturing small online communities managed by Local Government Units. They provide strong support for social interaction, social integration and strengthening of bayanihan (heroism) spirit (Congjuico, 2014). Today, it is known to be the second among the cities of the Philippines in internet-based employment, particularly in Information Technology-enabled Services (ITeS). This is brought about by its proportionally huge computer-educated population. Of the ten post-secondary schools in Iligan, seven offer degree courses in computer and three offer short-term courses in computer. Phuket, whose population is 3,86,605 (45.53 per cent using social media), is a prominent local government of 172 public agencies representing the central, provincial and local administration levels that used social media applications (Gunawong, 2015). 
This research used a combination of quantitative and qualitative research methods. The researchers used not only comparative-explanatory studies among the three cities in the ASEAN but also multiple-informant and secondary data analyses. All variables are operationalized into some indicators (Appendix) and transformed into a questionnaire in three languages: English, Indonesian and Thai. Primary data for the research were collected using a cross-sectional survey conducted in Bandung city, Indonesia; Iligan City, the Philippines; and Pukhet City, Thailand. Before the commencement of the survey, focus group discussion meetings were conducted in each city by inviting ten public employees and three ASEAN cities by conducting a pre-testing of the measuring instrument. In both exercises, the social media practitioners were involved to enable the assessment to have face validity. Such pre-field deployment research tasks allowed for the study's questionnaire to be improved by either rewording or deleting the items found to be ambiguous during the pilot phase. The pilot study, which involved public servants, facilitated the improvement of the research instruments and the determination of the reliability of the scale items. For content validity purposes, an extensive review of the literature was undertaken to gain an understanding of each construct and its items and to ensure that no important dimensions were neglected. Ten practitioners and ten academics/researchers of each city participated in this process. Each item in the questionnaire was reviewed for its content, scope and purpose. Their feedback resulted in several modifications to the items. Two rounds of pre-testing were carried out to ensure that the instrument was well designed and contained items that would really measure the constructs. The researchers proposed a research model showing the relationship among variables to be tested using structural equation model (SEM) (Table II).

\section{Findings}

Before the survey questionnaire was sent out, each respondent was contacted and asked to participate in the study. The questionnaire was designed in a way that respondents were asked to describe their degree of agreement with each statement on a five-point Likert scale (ranging from strongly disagree " 1 " to strongly agree " 5 ").

Table III presents the results regarding the public officials' perception on social media. The results in the three cities indicate that information and social media network are very important. Bandung and Pukhet's public officials recognized that information from social media is a more important information source than Iligan's public officials did. However, in terms of technical expertise or competency and reward in handling social media information, all respondents of the three cities have more and less similar responses. Social media governance needs technical competence in handling antivirus and antimalware. Further, controls must be installed on all systems and updated daily. In addition, content filtering technology should be used to either restrict or limit access to social media sites, and appropriate controls should also be installed on mobile devices such as smartphones

\begin{tabular}{lcccccc}
\hline & \multicolumn{2}{c}{ Bandung } & \multicolumn{2}{c}{ Iligan } & \multicolumn{2}{c}{ Pukhet } \\
Echelon & Population & Sample & Population & Sample & Population & Sample \\
\hline High rank & 14 & 7 & 15 & 5 & 10 & 10 \\
Middle rank & 54 & 13 & 34 & 15 & 24 & 22 \\
Lower rank & 76 & 23 & 78 & 20 & 29 & 18 \\
Sum & 144 & 43 & 127 & 40 & 63 & 40
\end{tabular}

Source: Human Resources data of each city

Table II.

Public employee engaged in social media use 
1 Public officials in my organization are very important sources of information

2 Information and social media network are very important

3 Our public officials have high level competency in handling social media

4 My organization has high level technical expertise

5 My organization has technical team consisting of senior officers

6 My organization explicitly give rewards to officials who become quality information source in social media

7 My organization often provide technical workshop in using social media Index

$\begin{array}{llllll}4.25 & 4.25 & 3.83 & 0.63 & 0.63 & 0.89 \\ 4.45 & 4.45 & 3.73 & 0.50 & 0.50 & 0.99 \\ 3.80 & 3.80 & 3.13 & 0.79 & 0.79 & 0.94 \\ 3.73 & 3.73 & 3.23 & 0.55 & 0.55 & 0.97 \\ 3.58 & 3.58 & 3.47 & 0.55 & 0.55 & 1.01 \\ 3.90 & 3.90 & 2.89 & 0.55 & 0.55 & 0.93 \\ & & & & & \\ 3.28 & 3.28 & 2.81 & 0.79 & 0.79 & 1.05 \\ 3.86 & 3.86 & 3.53 & & & \end{array}$

Table III. Personnel

Source: Primary data

(Linke and Zerfass, 2013). For the Bandung City Government, the information and communication agency is the main agency handling antivirus and filtering technology to restrict and limit access to social media sites. Meanwhile, Pukhet has an Information and Communication Technology Center(ICTC) which asks for specific software programs or topics that people would like to learn and then it compiles the requested topics and sends the information to in- and out-sourced academics with related expertise. The academics with expertise in related fields will then be invited to teach these topics in groups. An example of such a training project is a knowledge network group of retired or senior citizens using social media. Presently, many people are using Line for communicating.

In Iligan City, the Philippines, the ICTC is a section under the Office of the Mayor which takes care of the communication system of the local government of Iligan, including its website. The center is maintained by IT experts who are responsible for managing information that are vital in decision-making. There is no local legislation in the city that regulates the use of social media but restraints on ethical considerations are observed by users, as they are covered by applicable laws on libel and cyber-bullying. These considerations are important, as the use of social media in Iligan is pervasive even among those in grade school. Social media is used in the dissemination of school assignments and announcements (Table IV).

Does social media change communication patterns among units in internal municipal organization? Many prior studies confirmed that social media has changed the understanding of how government agencies can translate existing practices into a new online environment (Abrahamson and Rosenkopf, 1997; Rogers, 1976; Rogers and Shoemaker, 1971; Mergel, 2013). Even if central governments are catering to different audiences regarding the applicability of practices, they, therefore, transcend audiences and agency-specific content. Information via social media must be based on events like cases reported by netizens without normal patterns and planned reporting. Faced with these situations, city agencies need to col all information in a systematic way to make quick decisions.

Table $\mathrm{V}$ presents the results regarding public officials' perception of real-time coordination when responding to queries on social media information. The Bandung and Iligan public officials, rather than Phuket pubic officials, recognized that information from 


\begin{tabular}{|c|c|c|c|c|c|c|c|c|}
\hline No & Item & Bandung & $\begin{array}{l}\text { Mean } \\
\text { Phuket }\end{array}$ & Iligan & Bandung & $\begin{array}{l}\text { SD } \\
\text { Phuket }\end{array}$ & Iligan & $\begin{array}{l}\text { Case study of } \\
\text { three ASEAN }\end{array}$ \\
\hline 1 & $\begin{array}{l}\text { Social media gives efficient and effective } \\
\text { information distribution in my organization }\end{array}$ & 4.36 & 3.70 & 3.68 & 0.58 & 0.79 & 0.973 & \\
\hline 2 & $\begin{array}{l}\text { All members of my organization are aware of } \\
\text { the purpose of using social media }\end{array}$ & 3.85 & 3.53 & 3.36 & 0.74 & 0.68 & 0.723 & \\
\hline 3 & $\begin{array}{l}\text { My organization often conducts meetings to } \\
\text { follow up information obtained from social } \\
\text { media }\end{array}$ & 3.82 & 3.98 & 3.26 & 0.88 & 0.36 & 0.931 & 355 \\
\hline 4 & $\begin{array}{l}\text { Communication among units in my organization } \\
\text { become easier with social media }\end{array}$ & 4.16 & 4.20 & 3.38 & 0.86 & 0.41 & 0.953 & \\
\hline 5 & $\begin{array}{l}\text { Communication and coordination among } \\
\text { organizations become easier with social media }\end{array}$ & 4.26 & 2.70 & 3.34 & 0.68 & 0.85 & 0.838 & \\
\hline 6 & $\begin{array}{l}\text { I communicate with my supervisors via social } \\
\text { media }\end{array}$ & 4.03 & 2.70 & 3.18 & 0.81 & 0.65 & 846 & \\
\hline 7 & $\begin{array}{l}\text { Hierarchy is not important anymore in } \\
\text { communication using social media }\end{array}$ & 3.19 & 1.63 & 3.30 & 1.00 & 0.67 & 0.878 & \\
\hline 8 & $\begin{array}{l}\text { Our organization has mechanism and system } \\
\text { that can support each other in giving } \\
\text { information }\end{array}$ & 4.00 & 3.15 & 3.30 & 0.69 & 0.58 & 0.878 & \\
\hline & Index & 3.96 & 3.20 & 3.32 & & & & $\begin{array}{l}\text { Table IV. } \\
\text { Structure and }\end{array}$ \\
\hline \multicolumn{8}{|c|}{ Source: Primary data } & \\
\hline
\end{tabular}

social media is more an important information source. The public officials of the two cities confirm that they work in a team with other officers from other organizations/agencies in handling social media information. In summary, the internal organizational performance of the cities in handling social media is revealed at Figure 1.

Figure 1 summarizes the organizational conditions in three cities revealing that Bandung City has better internal organizational performance than the other two cities. Membership in Bandung City is mandated by making individual Twitter accounts of each city department. The legal and policy frameworks (membership) are very important for using Web. 2.0 in local government. However, in the three cities, only Bandung has a legal basis for social media use which was provided in a mayoral decree. All cities have no standard operating procedure in handling social media information. The importance of social media as source of information is recognized more by public officials of Bandung and Pukhet than by the public officials of Iligan. However, there in terms of technical competency and reward in handling social media information. Meanwhile, of structure and position, there are different practices in the three cities. In Bandung city, the Information and Communication Agency is the main agency in handling antivirus and filtering technology to restrict and limit access to social media sites. Meanwhile, Pukhet has a city ICT center which asks for specific software programs or topics that people would like to learn, compiles the requested topics, and then sends the information to in- and out-sourced academics with related expertise not to related agency. The academics with expertise in related fields will then be invited to teach the people in groups. An example of such a training project is a knowledge network group of retired or senior citizens using social media. Sometimes, the connections between groups or municipality government units have become difficult because the groups and units have time departmental rivalry and different decisionmaking cultures. In comparison with the other two cities, the Pukhet municipal government has not restructured its administrative functions and processes in terms of coordination and cooperation between different departments and different levels of government. 


\section{TG \\ 11,3}

No Item

Mean

SD

In my organization, we have officers who work
in a team with other officers from other

Bandung Phuket Iligan Bandung Phuket Iligan

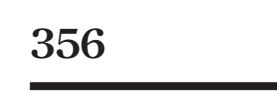

2 We have real-time coordination within our organization

3 in my organization, we have one unit that integrate various information from social media

4 Coordination of organizations/agencies to solve issues obtained from social media is an easy job

5 We often organize meeting events among organizations/agencies to share information

6 Good quality information in social media is based on accuracy and fact from the field

Table V.

Communication and information Index

$\begin{array}{llllll}3.73 & 2.80 & 3.77 & 0.88 & 0.72 & 0.843 \\ 4.05 & 3.00 & 3.49 & 0.45 & 0.82 & 0.742 \\ 3.73 & 2.80 & 3.38 & 0.72 & 0.41 & 0.751 \\ 3.47 & 3.00 & 3.31 & 0.86 & 0.55 & 0.965 \\ 3.74 & 2.43 & 3.45 & 0.79 & 0.55 & 1.034 \\ 3.95 & 2.55 & 3.39 & 0.70 & 0.50 & 1.103 \\ 3.78 & 2.76 & 3.45 & & & \end{array}$

Source: Primary data

Figure 1.

Research process

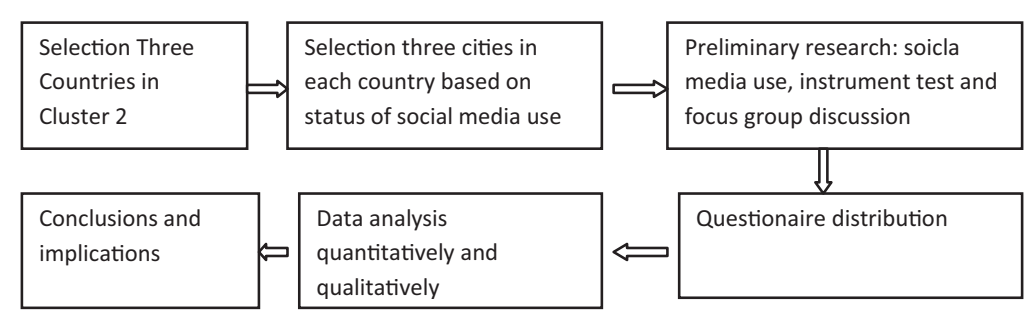

Figure 2 and Table VII present descriptive statistics and the bivariate correlations of this study's measures, respectively. Most of the relationships were not significant and were negative in the Pukhet City setting. In Bandung City, Indonesia, formal social media use (membership) variables were quite strongly and positively related to organizational personnel, position and structure. Meanwhile, in Iligan City, the Phillipines, only the formal social media use (membership) variable (0.225) was positively associated with position and structure. It is interesting to note that in Bandung and Iligan Cities, organizational culture was positively associated with public policy-making process. However, the proposed research model below is rejected empirically. This means that social media use (membership) has no effect on internal organization processes in the three cities (Tables VI and VII) (Figure 3).

\subsection{Bandung case}

Since Ridwan Kamil became Bandung's Mayor in 2013, he has been using social media, specifically Twitter, as a communication channel between government and citizens. Mayor Decree No. 1352/2014 laid down policies on communication between city government and citizen, namely:

- mandatory social media use in all city government agencies;

- mandatory use of LAPOR 1708 (REPORT 1708);

- photo-based report; and

- e-report of subdistrict program. 


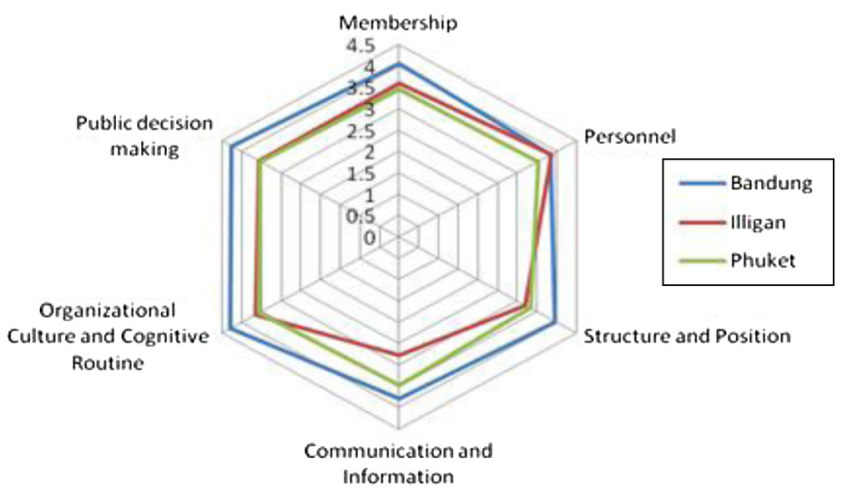

Case study of three ASEAN cities 357

Figure 2. Internal organization mapping in the three cities

The important reason for using social media (Twitter) is to shorten the communication path and to cut the bureaucratic red tape in the reporting system. The Bandung City Government has established 23 Twitter accounts of city agencies which are monitored by a local application portal called "Suara Bandung" (Bandung Voice). This portal assesses the performance of each account by counting response rates and sentiments (Figure 4).

It is interesting to find out that policymakers in Bandung City think that Web 2.0 technologies are appropriate as a space where citizens can interact with the city government in terms of information dissemination, dialogue, managing inputs from community and in prioritizing city programs.

\subsection{Pukhet City, Thailand}

In the case of Pukhet City, some respondents confirm that using social media in organizations is a good thing, but its effectiveness depends on which Line groups are posted and the group's membership. It is important that a powerful person be in that group Line, otherwise it would be the same typical complaining process that takes a long time. Moreover, the community or people must be strong and engaging. The data/information in Line are/is cannot be trusted always. Some are true, others are not. It depends on which side or group posted the information. Some people are chosen to highlight issues through city council members because they have close relationships with them. They believe that this may make the process faster than through Line, or this may get better solutions. Complaining via Line may not reach the mayor, as he may read messages in Line only once or few times per day. If only the staff read the Line messages, they may or may not report those messages within that day. It is unclear which problem is priority and no one can decide. Using social media in municipalities is not like using a communication tool. Rather, it seems to be a decision-making tool. It helps in making decisions faster. If a problem complaint comes into picture, it can be printed out as empirical evidence and ready to be sent out for further actions. It is obvious that Line is better than other regular ways, as it will not waste time, such as time for filling a form.

Mostly, social media is only a channel for organizational PR, not for receiving complaints from the people. "Complaining via Line cannot reach the Mayor. It may take many days until he reads and it will take longer until he decides to give an order". However, social media can create the power of community. When an important issue is posted, other members go to the Line group to share their opinions. For example, in case of a tunnel excavation, most of the group members disagreed; thus, once the issue was posted, they posted messages to resist that project. They have harmony. The power of community comes from the power of social media. 
TG
11,3

358

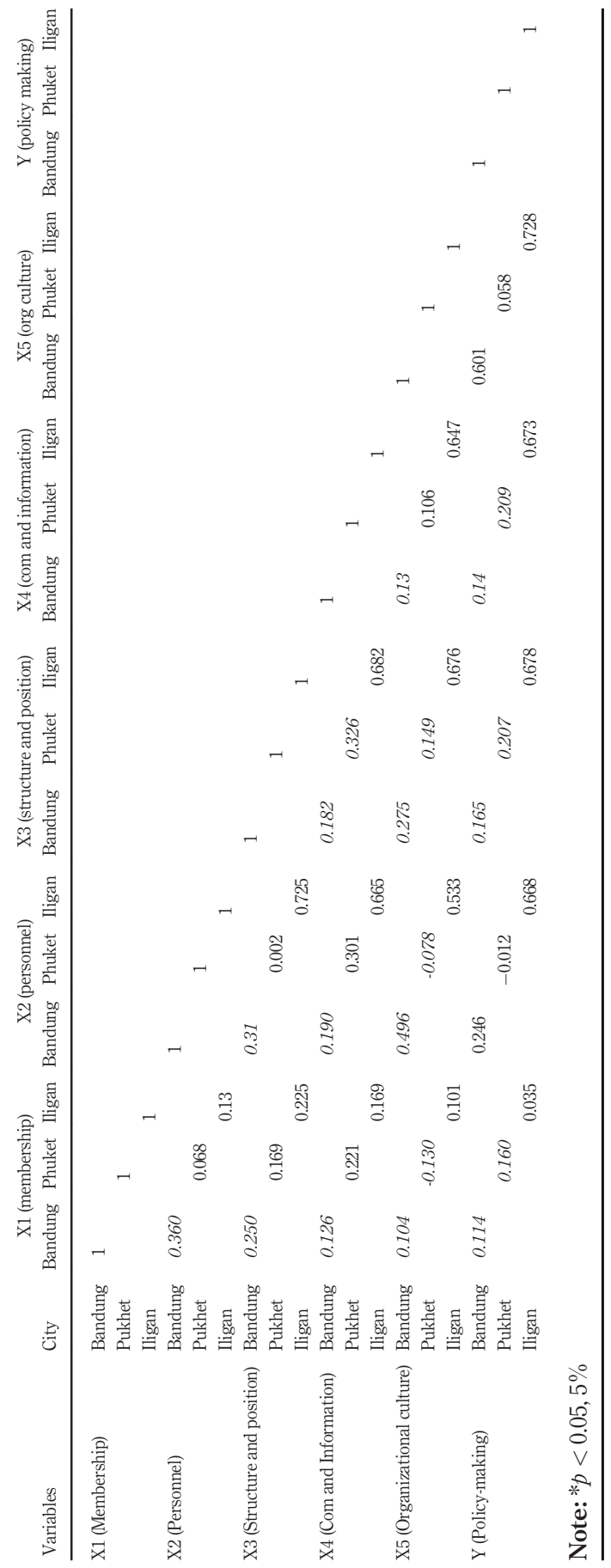

Table VI. 
Hypotheses

H1. The formal social media use (membership) in local government is associated with organizational communication and information

H2. The formal social media use (membership) in local government is associated with organizational culture H3. The formal social media us (membership) e in local government is associated with organizational personel H4. The formal social media use (membership) in local government is associated with position and structure H5. The formal social media use (membership) in local government is associated with organizational culture H6. The formal social media use (membership) is associated with public policy-making process

$H 7$. The communication and information is associated with public policy-making process

H8. The organizational culture is associated with public policy making process

H9. The personnel is associated with public policy-making process

H1O. The structure and position is associated with public policy making process

City

Case study of three ASEAN cities

$\begin{array}{lll}\text { REJECTED } & \text { REJECTED } & \text { REJECTED } \\ \text { REJECTED } & \text { REJECTED } & \text { REJECTED } \\ \text { ACCEPTED } & \text { REJECTED } & \text { REJECTED } \\ \text { ACCEPTED } & \text { REJECTED } & \text { ACCEPTED } \\ \text { REJECTED } & \text { REJECTED } & \text { REJECTED } \\ \text { REJECTED } & \text { REJECTED } & \text { REJECTED } \\ \text { REJECTED } & \text { REJECTED } & \text { ACCEPTED } \\ \text { ACCEPTED } & \text { REJECTED } & A C C E P T E D \\ \text { REJECTED } & \text { REJECTED } & A C C E P T E D \\ \text { REJECTED } & \text { REJECTED } & A C C E P T E D\end{array}$

Table VII. Hypotheses result testing

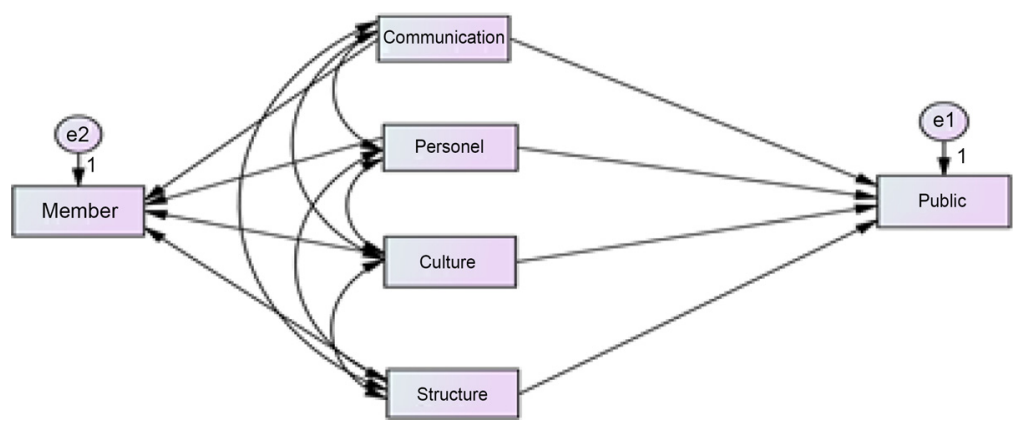

Figure 3.

Proposed research model

Although social media cannot be a panacea to cure all problems, it is a good tool for groups to voice their issues to city council members or the mayor. If a group has a powerful member, the group will benefit.

Social media may be a new thing in the context of Thailand which could lead to wrong usage. Sometimes, someone shares what was posted without careful thoughts. However, we can start seeing the development of social media use. Previously, we have wasted time for long meetings and travelling, but nowadays, we can have a meeting through Line. Complaining in the old fashion requires physically going to the organizations and meeting in person. We need to learn more on using social media continuously. For responding to complaints from communities, it depends on whether the issue makes a large impact on a community and how much the impact will be. If the issue has an impact on an individual only and not the public, or to a small area only, the response may be late.The effectiveness of using social media also 


\section{Figure 4.}

Response and sentiment rate of Bandung City departments via Twitter in November 2014

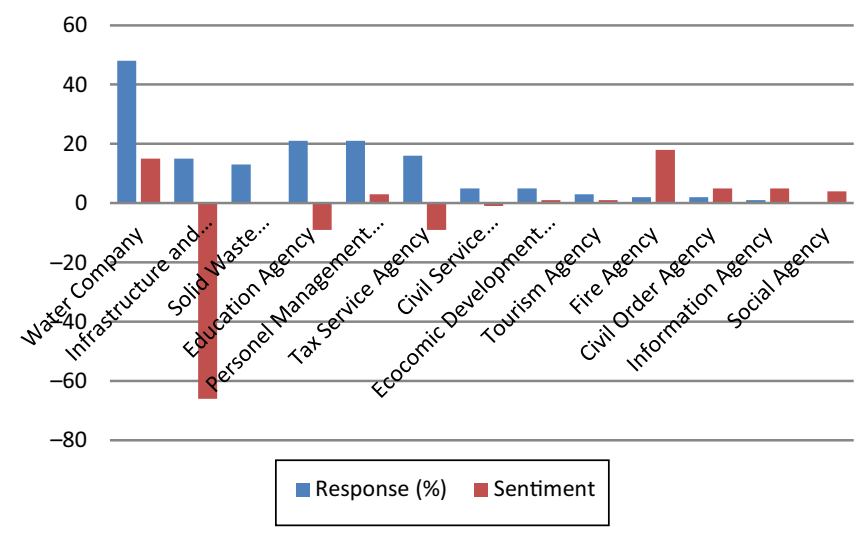

Source: SuaraBDG.Com

depends on how clear the organization's goals and policies are in relation to Line usage. A policy about receiving complaint procedure via Line should be clearly stated: for example, to whom should a complaint issue printout be sent to? Who should approve? That should be really clear-cut. Yet, presently, we do not know the procedure in Line for complaining. If the organizations have knowledge of the step-by-step complaint procedure in Line, the people or communities would benefit and they will have trust. It is possible that the people now lack trust on the social media tool of the city as the process is unknown, and using the social media is still in the developing/testing stage. The city also is on a trial-and-error phase regarding social media use. Some of the reasons why people choose to make a complaint through city council members is that the people may not believe in Line, and that city council members play an important role in assigning jobs, and they always try to take action on jobs to keep people's votes. One respondent said that social media in organizations is used only for the city PR to spread information to the community.

\subsection{Iligan City, Philippines}

For public information, Iligan City maintains a website where vital information regarding the city and updates of its operations are posted for public consumption. The city also has a Facebook account where public opinions, complaints and emergency notes can be posted. Public engagements are facilitated through the social media and through the broadcast media. Announcers of many radio stations of the city are connected to the public through Facebook and they are supplied with daily information from the public which enriches the database for their daily announcements and commentaries. The pervasive use of Facebook among Iliganons, which was made possible by the introduction of the mobile phone with its capability to manage both written and graphical data, made social media a very important means of communication in the city.

In Iligan City, Phillipines, the ICTC is a section under the Office of the Mayor which takes care of the communication system of the local government, including its website. The center is maintained by IT experts who are responsible in managing information that are vital in decision-making. However, also Facebook's collected information does not have much impact on decision-making process because each department has its own mechanism. 


\section{Discussion}

This research found that social media use has not yet affected internal organizational process in the three cities. Also, social media use is not appropriated as a space for citizengovernment interaction. It is used only for information dissemination for the public and in gathering feedbacks and opinions from the citizens. This shows that social media is used more for collecting information from citizens, but not for involving them in the decisionmaking process. This finding confirms McNutt's (2014) research findings that health departments in the USA which are slow to adopt or non-adopters of social media may be facing organizational barriers common to governmental public health organizations. From the resource dependency view of power, e.g., knowledge, information, money and social capital (Conrad, 1983; Pfeffer and Davis-Blake, 1987; Scott, 2004), each organization has a unique power structure that could greatly influence how internal communication is happening. If such organization places strong power in the top leader, all internal informations are concentrated on him/her (Rana et al., 2013; Nurmandi and Kim, 2015). On the other hand, in the context of social media, the potential source of power for individuals in organizations may become less dependent on others in an organization, through the ease of associations made through social media use (Treem and Leonardi, 2012). In the case of Iligan and Phuket, the local government lags in laying down the legal basis for the use of social media in policy-making. This could be because of technological barrier or the inability to control the use of social media which spawns the fear that power will shift to the citizens to the disadvantage of the political elites in the local government.

Governments' organizational culture is risk averse, and without a basic set of best practices on managing risk, support for social media use may be undermined by existing administrative cultures implying some loss of control. And this finding also is in accord with the research finding of Sobaci and Karkin (2013) about the Twitter use and activity of a mayor in Turkey. They found that only 12.4 per cent of the mayor's Twitter activities are aimed at collecting opinions, suggestions and complaints of citizens, while the rest is used for personnel matters. Cultural barriers to open government through social media-based public engagement need to be addressed. Senior management should recognize, celebrate and advertise success stories of public engagement to facilitate cultural change toward openness and transparency (Lee and Kwak, 2012; Ho«chtl et al., 2011). While social media may enhance transparency, it will take time before it will be fully integrated into the organizational culture of local government units. Its impact into the way communication and decision-making are done is revolutionary which in effect threatens the old order of doing things, thus eliciting a sort of negative reaction from the generation of the so called "digital immigrants" or people who were initiated late in the use of computers. We found a lot of social media services which were used in the second step to retrieve governmental accounts which have no link from their city government website (Mainka et al., 2015). This findings also confirm Mergel's (2013) previous study on social media use in US central government which stated that social media serves a levelling function especially during the early experimentation phase when all social media practitioners operated in a gray area not knowing if their practices are consistent with the existing rules and regulations.

\section{Conclusions}

Most of the relationships were negative and not significant in the setting of the three cities

- These findings confirm previous research findings that social media use in local government is only for information dissemination. 
TG

11,3

362

- In Bandung City, Indonesia, formal social media use (membership) variables were quite strongly positively related to organizational personnel, position and structure.

- Meanwhile, in Iligan City, Phillipines, only the formal social media use (membership) variable was positively associated with position and structure.

- It is interesting to note that in Bandung and Iligan, organizational culture was positively associated with public policy-making process. However, the proposed research model is rejected based on the empirical data.

- This means that social media use (membership) has no effect on internal organization processes in the three cities.

\section{Limitations and implications}

However, there are some limits and obstacles to social media use. First, social media is used only for the city's public relations to spread information to the community. Second, social media might not be trusted because of the fear that complaints may not be responded to due to identify priorities and consequently the failure to decide, compared to directly complaining to the mayor or to any city council member, in which concrete responses can be given to answer their complaints or demands.

This research covers only three cities in the ASEAN countries and the findings cannot be generalized to other cities. Second, this research looks only at the supply-side dimension or government organization side. However, the findings of this study confirm the previous research that social media use in local government is only for information dissemination and for receiving feedbacks or inputs from the citizens. In practical implication, social media use needs the change of organizational culture. Ontherwise, if the hierarchy decision-making process remains in local government, social media use becomes a tool for the passive internal administration of the city rather than a tool for an active one. However, online culture model via social media is needed within government organization for changes in leadership, policy and governance. The use of social media could improve more egalitarian organizational culture and faster decision-making process in government organization. The social media use needs the new way of organizational structuring in terms of virtual team rather than bureaucratic form of organizational structure.

\section{References}

Abrahamson, E. and Rosenkopf, L. (1997), "Social network effects on the extent of innovation diffusion: a computer simulation”, Organization Science, Vol. 8 No. 3, pp. 289-309.

Achterbergh and Vrients (2009), Organizations, Social System Conducting Experiments, Springer, Berlin Heidelberg.

Aichholzer, G. and Schmutzer, R. (2000), "Organizational, technological and regulatory challenges for realizing electronic government”, ECIS 2000: 1136-1143.

Altheide, D.L. (2004), "Media logic and political communication", Political Communication, Vol. 21 No. 3, pp. 293-296.

Beynon-Davies, P. (2007), "Models for e-government”, Transforming Government: People, Process and Policy, Vol. 1 No. 1, pp. 7-28.

Chadwick, A. (2011), "Britain's first live televised party leaders debate: from the news cycle to the political information cycle", Parliamentary Affairs, Vol. 64 No. 1, pp. 24-44.

Congjuico, T. (2014), "Social media for risk management and emergency response for Philippine local government units", Journal of Management and Development Studies, Vol. 3 No. 1. 
Conrad, J. (1983), Times Remembered, Cambridge University Press, London, p. 218.

CS Transform (2010), "Citizen service transformation: a manifesto for change in the delivery of public services", CS Transform (White Papers).

Deacon, T.W. (2001), The Symbolic Species: The Co-Evolution of Language and the Brain, Penguin, Harmondsworth.

Dunleavy, P., Margetts, H., Bastow, S. and Tickler, J. (2005), "New public administration is dead: long live digital-era governance", Journal of Public Administration Research and Theory, Vol. 16 No. 3, pp. 467-494.

Figenschou, T.U. (2015), Al Jazeera and the Global Media Landscape: The South is Talking Back, Routledge, New York, NY.

Fulla, S. and Welch, E. (2002), "Framing virtual interactivity between government and citizens: a study of feedback systems in the Chicago Police Department", Proceedings of the 35th Annual Hawaii International Conference on System Sciences, 2002: HICSS, IEEE, p. 11.

Gordon, R.A. (2000), Eating Disorders: Anatomy of A Social Epidemic, Blackwell Publishers.

Gottschalk, P. (2009), "Der Kreative Link von Print zu Online-Erhebung Uber Die Zahl Der Moglich Keiten Fur Webverweise”, Deutschen Tages Zeitungen Keiten Fur Webverweise, Deutschen Tageszeitungen Steinbess University, Berlin/Stuttgart.

Graham, M. and Avery, E.J. (2013), available at: www.bdzv.de/fileadmin/bdzv_hauptseite/aktuell/ publikationen/2016/ZDF_2016.pdf

Gunawong, P. (2015), "Open government and social media: a focus on transparency", Social Science Computer Review, Vol. 33 No. 5, pp. 587-598.

Hendry, J. and Seidl, D. (2003), "The structure and significance of strategic episodes: social systems theory and the routine practices of strategic change", Journal of Management Studies, Vol. 40 No.1, pp. 175-196.

Hernes, T. and Bakken, T. (2003), "Implications of self-reference: Niklas Luhmann's autopoiesis and organization theory”, Organization Studies, Vol. 24 No. 9, pp. 1511-1535.

Ho«chtl, J., Parycek, P. and Sachs, M. (2011), "E-participation readiness of Austrian municipalities", Transforming Government: People, Process and Policy, Vol. 5 No. 1, pp. 32-44, doi: 10.1108/ 17506161111114635.

Imurana, B.A., Haruna, R.K. and Kofi, A.N. (2014), "The politics of public policy and problems of implementation in Africa: an appraisal of Ghana's National Health Insurance Scheme in Ga East District”, Journal of Humanities and Social Science, Vol. 4 No. 4.

Internet Society (2016), "Unleashing the potential of the Internet for ASEAN economies", www.internetsociety. org/sites/default/files/ISOC_ASEAN_Digital_Economy_Executive\%20Summary_s_0.pdf (accessed 3 March 2017).

Ipsos-Markinor (2012), "Interconnected world: communication \& social networking", available at: $\mathrm{http} / /$ ipsosmarkinor.co.za/news/interconnected-world-communication-socialnetworking (accessed 3 March 2017).

Johannessen, M.R., Johannessen, M.R., Sæbø, Ø., Sæbø, Ø., Flak, L.S. and Flak, L.S. (2016), "Social media as public sphere: a stakeholder perspective", Transforming Government: People, Process and Policy, Vol. 10 No. 2, pp. 212-238.

Karantzeni, D. and Gouscos, D.G. (2013), "eParticipation in the EU: re-focusing on social media and young citizens for reinforcing European identity", Transforming Government: People, Process and Policy, Vol. 7 No. 4, pp. 477-500.

Kaplain, A. and Haelein, M. (2010), "User of the world, unite! the challenges and opportunities of social media", Business Horizon, Vol. 53 No. 1, pp. 59-68.

Kavanaugh, A.L., Fox, E.A., Sheetz, S.D., Yang, S., Li, L.T., Shoemaker, D.J. and Xie, L. (2012), "Social media use by government: from the routine to the critical", Government Information Quarterly, Vol. 29 No. 4, pp. 480-491. 
Khan, G., Young Yoon, H., Kim, J. and Woo Park, H. (2014), "From e-government to social government: Twitter use by Korea's central government", Online Information Review, Vol. 38 No. 1, pp. 95-113.

Kieser, A. and Leiner, L. (2009), "Why the rigour-relevance gap in management research is unbridgeable”, Journal of Management Studies, Vol. 46 No. 3, pp. 516-533.

Klievink, B. and Janssen, M. (2009), "Realizing joined-up government: dynamic capabilities and stage models for transformation", Government Information Quarterly, Vol. 26 No. 2, pp. $275-284$.

Klischewski, R. (2004), "Infrastructure for an E-Government process portal", European Conference, MCIL, Reading, pp. 233-245.

Kubicek, H., Cimander, R. and Scholl, H.J. (2009), Organizational Interoperability in E-Government, Springer-Verlag, Berlin, Heidelberg.

Lazer, D., Pentland, A.S., Adamic, L., Aral, S., Barabasi, A.L., Brewer, D. and Jebara, T. (2009), "Life in the network: the coming age of computational social science", Science (New York, NY), Vol. 323 No. 5915, p. 721.

Leavey, J. (2013), "Social media and public policy: what is the evidence?", available at: www. alliance4usefulevidence.orgwww.alliance4usefulevidence.org

Lee, G. and Kwak, Y.H. (2012), “An open government maturity model for social media-based public engagement”, Government Information Quarterly, Vol. 29 No. 4, pp. 492-503.

Linder, J.R.W. and Nicole, E. (2012), "Relationally aggressive media exposure and children's normative beliefs: does parental mediation matter?”, Family Relations, Vol. 61 No. 3, pp. 488-500.

Linke, A. and Zerfass, A. (2013), "Social media governance: regulatory frameworks for successful online communications", Journal of Communication Management, Vol. 17 No. 3, pp. 270-286.

Luhmann, N. (1986), "The autopoiesis of social systems", in Geyer, F. and Van der Zouwen, J. (Eds), Sociocybernetic Paradoxes: Observation, Control and Evolution of Self-steering Systems, Sage, London, pp. 171-192.

Luhmann, N. (2000), Organization and Decision, West-deutscher Verlag, Opladen.

Luhmann, N. (2003), “Organization”, in Bakken, T. and Hernes, T. (Eds), Autopoietic Organization Theory: Drawing on Niklas Luhmann's Social Systems Perspective, Copenhagen Business School Press, Oslo, pp. 31-52.

Luhmann, N. (2005), Tillid-en Mekanisme Til Redukton of Social Kompleksitet, Hans Reitzels Forlag, Kobenhavn.

Luhmann, N. (2006), Organisation und Entscheidung, VS Verlag fur Sozialwissenschaften, Wiesbaden.

Mainka, A., Hartmann, S., Stock, W.G. and Peters, I. (2015), "Looking for friends and followers: a global investigation of governmental social media use", Transforming Government: People, Process and Policy, Vol. 9 No. 2, pp. 237-254.

Mirchandani, D.A., Johnson, J.H., Jr. and Joshi, K. (2008), "Perspectives of citizens towards egovernment in Thailand and Indonesia: a multigroup analysis", Information System Frontiers, Vol. 10 No. 4, pp. 483-497.

Mergel, I. (2013), "Social media adoption and resulting tactics in the US federal government", Government Information Quarterly, Vol. 30 No. 2, pp. 123-130, available at: http://dx.doi.org/ 10.1016/j.giq.2012.12.004

Mezgar, I. (Ed.) (2006), Integration of ICT in Smart Organizations, Idea Group Publishing, Hershey.

Nurmandi, A. (2015), "Inovasi Organisasi Publik: Implementasi Knowledge Management mendorong Inovasi", Jurnal Kebijakan dan Administrasi Publik, Vol. 10 No. 2, pp. 133-148.

Nurmandi, A. and Kim, S. (2015), "Making e-procurement work in a decentralized procurement system: a comparison of three Indonesian cities", International Journal of Public Sector Management, Vol. 28 No. 3, pp. 198-220. 
Nyong'o, P.A. (1998), "Review and critique of current development strategies in Africa”, in Kibwana, K. (Ed.), Constitutional Law and Policies in Africa: A Case of Nairobi, Faculty of Law, University of Nairobi, Nairobi.

Oginni, O.S. (2015), "Social media and public policy process in Africa: enhanced policy process in digital age", The Journal of Sustainable Development, Vol. 14 No. 2, pp. 158-172.

Panagiotopoulos, P., Sams, S., Elliman, T. and Fitzgerald, G. (2011), "Do social networking groups support online petitions?”, Transforming Government: People, Process and Policy, Vol. 5 No. 1, pp. 20-31.

Pfeffer, J. and Davis-Blake, A. (1987), "The effect of the proportion of women on salaries: the case of college administrators", Administrative Science Quarterly, pp. 1-24.

Pinzón (2013), "Beyond connectivity: the impacts of social media in urban development in Puerto Ayora", DPU Working Paper No 160.

Rana, N.P., Dwivedi, Y.K. and Williams, M.D. (2013), "Analysing challenges, barriers and CSF of egov adoption”, Transforming Government: People, Process and Policy, Vol. 7 No. 2, pp. 177-198.

Rogers, E.M. (1976), "Communication and development: the passing of the dominant paradigm", Communication Research, Vol. 3 No. 2, pp. 213-240.

Rogers, E.M. and Shoemaker, F.F. (1971), Communication of Innovations; A Cross-Cultural Approach.

Sáez-Martín, A., Haro-de-Rosario, A. and Caba-Perez, C. (2014), "A vision of social media in the Spanish smartest cities", Transforming Government: People, Process and Policy, Vol. 8 No. 4, pp. 521-544.

Schillemans, T. (2012), Mediatization of Public Services: How Organizations Adapt to News Media, Frankfurt am Main, Peter Lang.

Scholl, H.J., Kubicek, H., Cimander, R. and Klischewski, R. (2012), "Process integration, information sharing, and system interoperation in government: a comparative case analysis", Government Information Quarterly, Vol. 29 No. 3, pp. 313-323, doi: 10.1016/j.giq.2012.02.009.

Scott, W.R. (2004), “Institutional theory”, Encyclopedia of Social Theory, Vol. 11, pp. 408-414.

Seidl, D. (2004), Luhmann's Theory of Autopoietic Social Systems, Ludwig-Maximilians-Universität München-Munich School of Management.

Simon, H., Roth, M.S., Madden, T.J. and Hudson, R. (2015), "The effects of social media on emotions, brand relationship quality, and word of mouth: an empirical study of music festival attendees", Tourism Management, Vol. 47, pp. 68-76.

Sobaci, M.Z. and Karkin, N. (2013), "The use of twitter by mayors in Turkey: tweets for better public services?”, Government Information Quarterly, Vol. 30 No. 4, pp. 417-425.

Spiliotopoulou, L., Charalabidis, Y.N., Loukis, E. and Diamantopoulou, V. (2014), "A framework for advanced social media exploitation in government for crowdsourcing", Transforming Government: People, Process and Policy, Vol. 8 No. 4, pp. 545-568.

Strömbäck, J. (2011), "Mediatization and perceptions of the media's political influence", Journalism Studies, Vol. 12 No. 4, pp. 423-439.

Terwiesch, C., Loch, C.H. and Meyer, A.D. (2002), "Exchanging preliminary information in concurrent engineering: alternative coordination strategies", Organization Science, Vol. 13 No. 4, pp. 402-419.

Treem, J.W. and Leonardi, P.M. (2012), "Social media use in organizations: exploring the affordances of visibility, editability, persistence, and association”, Communication Yearbook, Vol. 36, pp. 143-189.

Tsohou, A., Lee, H. and Irani, Z. (2014), "Innovative public governance through cloud computing: Information privacy, business models and performance measurement challenges", Transforming Government: People, Process and Policy, Vol. 8 No. 2, pp. 251-282.

Waller, L. and Genius, A. (2015), "Barriers to transforming government in Jamaica: challenges to implementing initiatives to enhance the efficiency, effectiveness and service delivery of government through ICTs (e-Government)", Transforming Government: People, Process and Policy, Vol. 9 No. 4, pp. 480-497. 
Weerakkody, V. (2009), Applied Technology Integration in Governmental Organizations: New E-Government Research, Information Science Reference Hershey, New York, NY.

Zammuto, R.F., Gifford, G. and Goodman, E.A. (1999), "Managerial ideologies, organisation culture and the outcomes of innovation: a competing values perspective", in Ashkanasy, N.M., Wilderom, C.P.M. and Peterson, M.F.(Eds) The Handbook of Organisational Culture and Climate, Sage, Thousand Oaks, CA.

Further reading

Antoniadis, K., Zafiropoulos, K. and Vrana, V. (2016), "A method for assessing the performance of e-Government Twitter accounts", Future Internet, Vol. 8 No. 2, p. 12.

Ashari, H.E. and Parsei, M. (2014), "Application of the multi-criteria decision method ELECTRE III for the Weapon Selection”, Decision Science Letters, Vol. 3 No. 4, pp. 511-522.

Barile, S. and Polese, F. (2010), "Smart service systems and viable service systems: applying systems theory to service science", Service Science, Vol. 2 Nos 1/2, pp. 21-40.

Bonsón, E., Torres, L., Royo, S. and Flores, F. (2012), "Local e-government 2.0: social media and corporate transparency in municipalities", Government Information Quarterly, Vol. 29 No. 2, pp. 123-132.

Bourne, H.R. and Zastrow, M.V. (2007), "Drug receptors \& pharmacodynamic" in Dalam, K. and Bertram, G. (Eds), Basic \& Clinical Pharmacology, 10th ed., Lange Medical Publications, New York, NY, pp. 11-33.

Carlo Bertot, J., Jaeger, P.T. and Grimes, J.M. (2012), "Promoting transparency and accountability through ICTs, social media, and collaborative e-government”, Transforming Government: People, Process and Policy, Vol. 6 No. 1, pp.78-91.

Charalabidis, Y., Loukis, E.N., Androutsopoulou, A., Karkaletsis, V. and Triantafillou, A. (2014), "Passive crowdsourcing in government using social media", Transforming Government: People, Process and Policy, Vol. 8 No. 2, pp. 283-308.

Easton, D. (1965), A Framework for Political Analysis, Prentice-Hall, Englewood Cliffs, NJ.

Fuchs, C. (2007), Internet and Society: Social Theory in the Information Age, Routledge, New York, NY.

Janowski, M. and Kerlogue, F. (2007), Kinship and Food in South East Asia, NIAS, Copenhagen.

Kadushin, C. (2012), Understanding Social Networks: Theories, Concepts, and Findings, Oxford University Press, Oxford.

Kaewkitipong, L., Chen, C. and Ractham, P. (2012), "Lessons learned from the use of social media in combating a crisis: a case study of 2011 Thailand flooding disaster", a paper presented at Thirty Third International Conference on Information Systems, Orlando, available at: https:/pdfs. semanticscholar.org/9224/5f2347e67dec09567c548fe3c528edd9d62e.pdf

Kaewkitipong, L., Ractham, P. and Firpo, D. (2012), “The use of Facebook in an intoductory MIS course: social constructivist learning environment", Decision Sciences Journal of Innovative Education, Vol. 10 No. 2, pp. 165-188, doi: 10.111/j.1540-4609.2011.00337x.

Knudsen, M. (2005), "Managing the paradox of decision making", in Seidl, D. and Becker, K.H. (Eds), Niklas Luhmann and Organization Studies, CBS Press and Liber, Copenhagen, Malmö.

Krutern, V. (2012), "Social network site, a citizen's mouthpiece in time of crisis: the study of Facebook use in Thailand floods 2011", Master thesis, Gotenborg Universitet, Gothenburg.

Kuzma, J. (2010), “Asian government usage of Web 2.0 social media”, European Journal of ePractice, Vol. 9, pp. 1-13.

Luhmann, N. (1989), "Law as a social system”, Northwestern University Law Review, Vol. 83 Nos 1/2, pp. 136-150.

Luhmann, N. (1992), “What is communication?”, Communication Theory, Vol. 2 No. 3, pp. 251-259.

Luhmann, N. (1995), Social Systems, Stanford University Press, Stanford, CA.

Malhotra, A., Majchrzak, A. and Rosen, B. (2007), "Leading virtual teams", Academy of Management Perspectives, Vol. 21 No. 1, pp. 60-70. 
Mamic, L. and Almaraz, I. (2014), "How the larger corporations engage with stakeholders through twitter", International Journal of Market Research, Vol. 55 No. 6, p. 851.

Marjanovic, O., Hallikainen, P., Balnave, N., Patmore, G. and Rittau, Y. (2015), Social Media Use in Australian Co-operatives: Current Applications and Future Opportunities, Cooperative Enterprises, Australia, Italy, p. 231.

Mergel, I. (2016), "Social media institutionalization in the US federal government", Government Information Quarterly, Vol. 33 No. 1, pp. 142-148.

Mickoleit, A. (2014), "Social media use by governments: a policy primer to discuss trends, identify policy opportunities and guide decision makers", OECD Working Papers on Public Governance No 26, OECD Publishing, Paris.

Mundy, D. and Umer, Q. (2012), "United Kingdon local authority challenges in the use of Twitter and other social media", SOTICS 2012: The Second International Conference on Social Ecolnformatics, Venice, 21-26 October 2016.

Mykkänen, M. and Tampere, K. (2014), "Organizational decision making: the Luhmannian decision communication perspective”, Journal of Business Studies Quarterly, Vol. 5 No. 4, pp. 131-146.

Oliveira, G.H.M. and Welch, E.W. (2013), "Social media use in local government: linkage of technology, task, and organizational context", Government Information Quarterly, Vol. 30 No. 4, pp. 397-405.

Panagiotopoulos, P., Bigdeli, A.Z. and Sams, S. (2014), "Citizen-government collaboration on social media: the case of Twitter in the 2011 riots in England", Government Information Quarterly, Vol. 31 No. 3, pp. 349-357.

Pande, A.S. (2003), "An emergent complex systems perspective on e-governance", International Conference on E-Governance, pp. 18-20.

Razmerita, L., Kirchner, K. and Nabeth, T. (2014), "Social media in organizations: leveraging personal and collective knowledge processes", Journal of Organizational Computing and Electronic Commerce, Vol. 24 No. 1, pp. 74-93.

Reddick, C.G. and Norris, D.F. (2013), "Social media adoption at the American grass roots: Web 2.0 or 1.5?”, Government Information Quarterly, Vol. 30 No. 4, pp. 498-507.

Schatten, M. and Bača, M. (2010), "A critical review of autopoietic theory and its applications to living, social, organizational and information systems”, Društvena Istraživanja, Vol. 108 No. 109, pp. 4-5.

Scholl, H.J., Kubicek, H., Cimander, R. and Klischewski, R. (2012), "Process integration, information sharing, and system interoperation in government: a comparative case analysis", Government Information Quarterly, Vol. 29 No. 3, pp. 313-323, doi: 10.1016/j.giq.2012.02.009.

Schulz, W. (2002), Wandlungen Der Einstellungen Zum Tode in Prufendes Denken: Essays Zur Wiederbelebung Der Philosophie, Klopter and Meyer, Tubingen, pp. 95-113.

Serrat, O. (2010), Social Media and the Public Sector, Asian Development Bank, Manila, available at: $\mathrm{http} / / /$ digitalcommons.ilr.cornell.edu

Sivarajah, U. and Irani, Z. (2013), A Theoretical Model for the Application of Web 2.0 in E-Government.

Sobaci, M.Z. (2016), Social Media and Local Governments: Theory and Practice, Springer, Charm.

Tubin, D. (2007), "When ICT meets schools: differentiation, complexity and adaptability", Journal of Educational Administration, Vol. 45 No. 1, pp. 8-32.

Welch, E.W. (2005), "Linking citizen satisfaction with e-Government and trust in government", Journal of Public Administration Research and Theory, Vol. 15 No. 3, pp. 163-185.

Young Foundation (2010), “Theyoungfoundationandweb”, available at: http://youngfoundation.org/wpcontent/uploads/2012/11/The-Young-Foundation-and-the-Web-Digital-Social-InnovationSeptember-2010.pdf (accessed 3 March 2017).

Zheng, L. and Zheng, T. (2014), "Innovation through social media in the public sector: Information and interactions", Government Information Quarterly, Vol. 31 No. 3, pp. 106-111. 


\section{Membership}

- There is a legal foundation of social media use in city government.

- Availability of local government institution that is responsible for handling social media.

- Standard operating procedure for handling social media.

\section{Communication pathway}

- Response times.

- Virtual platform for an informal and open sharing of thoughts, expectations, assumptions and values which offers an opportunity to form alliances of collective.

\section{Personnel}

- Qualification of personnel.

- Chief information capability.

\section{Position}

- Integration ICT to organization.

- Virtual coordination.

- Process integration and information integration (sharing).

\section{Decision and planning}

- Prioritization of information exchange as critical to service delivery.

- Organizational stress dependent on depth of action.

\section{Organization culture and cognitive routine}

- Degree of response, non-response, generic response, direct informational response, referred informational response and referred action.

- Role reassignment.

- Structural change/intraorganizational networking.

- Understanding of functions between units.

\section{Public policy}

- The number of demands based on social media information.

- The level of completion of public demands.

- The effectivity of completion of public demands. 


\section{Appendix 2. Local government official questionnaire}

For the purposes of this research, social media is defined as that subset of Web 2.0 having the characteristic of being social and interactive in nature-allowing (but not requiring) two way information exchange between indivual entities, in this case between government and citizens, institutions and others entities.

Please provide your name, title, and state in the boxes below.

$\begin{array}{ll}\text { a. } & \text { Name : } \\ \text { b. Title : } & \\ \text { c. Organization : } \\ \text { d. City : } \\ \text { e. Email Address : } \\ \text { f. Phone Number : }\end{array}$

\section{Membership}

Please circle one choice for each of the following statements

( 1 =strongly disagree, 2 =disagree, $3=$ nor disagree nor agree, $4=$ agree, $5=$ strongly agree, $\mathrm{X}=$ do not know

\begin{tabular}{|l|l|l|l|l|l|l|l|}
\hline & \multicolumn{1}{|l|}{} & 1 & 2 & 3 & 4 & 5 & X \\
\hline 1 & $\begin{array}{l}\text { Our organization has clear direction in using social media for } \\
\text { public policy }\end{array}$ & & & & & \\
\hline 2 & $\begin{array}{l}\text { Our organization has good regulation or guideline in using } \\
\text { soical media for public policy including personal use }\end{array}$ & & & & \\
\hline 3 & $\begin{array}{l}\text { Citizen engagement is very important issue for social media } \\
\text { use }\end{array}$ & & & & & & \\
\hline 4 & Social media covered official record-keeping & & & \\
\hline 5 & $\begin{array}{l}\text { Our organization has standard in keeping and managing } \\
\text { information from social media }\end{array}$ & & & & & \\
\hline 6 & $\begin{array}{l}\text { Our organization has best pratices in managing information } \\
\text { from social media }\end{array}$ & & & & &
\end{tabular}

1. Please indicate wheter you have developed guidance for social media use in any or all the following form

\begin{tabular}{|l|l|l|l|l|}
\hline & Local government & Agency & Program & None \\
\hline Policies & & & & \\
\hline Best practices & & & & \\
\hline Standards & & & & \\
\hline $\begin{array}{l}\text { Acceptable } \\
\text { use guidance }\end{array}$ & & & & \\
\hline
\end{tabular}

2. What are the primary reasons your state government is using social media technologies? Please check all that apply

a. Citizen engagement

b. Business engagement

c. Govermment engagement

d. City govermment employee engagement

e. Process improvement

f. Open govermment

g. Public information, outreach, and awareness

h. Reduced need for agency resources (e.g.,less email, phone calls, open records / FOI requests)

i. Not using

3. Your city government's social media adoption is primarily through

a. No-cost, hosted external platform (facebook,twitter,youtube, etc.)

b. Off-the-shelf, purchased software

c. Custom applications developed internally 
4. If you are using no-cost, hosted solutions, please indicate the tool(s) your agency uses to engage with citizens, employees, and/or communities of practice.

\begin{tabular}{|c|c|c|c|}
\hline & Citizens & Employees & Communities of Practice \\
\hline \multicolumn{4}{|l|}{ Facebook } \\
\hline \multicolumn{4}{|l|}{ Twitter } \\
\hline \multicolumn{4}{|l|}{ You Tube } \\
\hline \multicolumn{4}{|l|}{ Linkedin } \\
\hline \multicolumn{4}{|l|}{ Flickr } \\
\hline \multicolumn{4}{|l|}{ My Space } \\
\hline \multicolumn{4}{|l|}{ Second Life } \\
\hline \multicolumn{4}{|l|}{ Ning } \\
\hline \multirow{2}{*}{\multicolumn{4}{|c|}{ Vimeo }} \\
\hline & & & \\
\hline \multicolumn{4}{|l|}{ Delicious } \\
\hline \multicolumn{4}{|l|}{ Gov Loop } \\
\hline Blogs & & & \\
\hline Foursquare & & & \\
\hline
\end{tabular}

5. The following issues have commonly constrained broader use of social media or represent potential risks. Please indicate below your level of concern in each area.

( 1 =strongly disagree, 2 =disagree, 3 = nor disagree nor agree, 4 = agree, $5=$ strongly agree, $X$ = do not know)

\begin{tabular}{|c|c|c|c|c|c|c|}
\hline & 1 & 2 & 3 & 4 & 5 & $\mathrm{X}$ \\
\hline $\begin{array}{l}\text { Lack of executive/Management } \\
\text { Support }\end{array}$ & & & & & & \\
\hline $\begin{array}{l}\text { Lack of quantifiable business } \\
\text { benefit }\end{array}$ & & & & & & \\
\hline Lack of resources to support & & & & & & \\
\hline $\begin{array}{l}\text { Lack of resources to } \\
\text { monitor/control }\end{array}$ & & & & & & \\
\hline Terms of service (legal) issues & & & & & & \\
\hline Lack of control over providers & & & & & & \\
\hline Records retention issues & & & & & & \\
\hline Privacy concerns & & & & & & \\
\hline Security concerns & & & & & & \\
\hline Lack of governance framework & & & & & & \\
\hline Accessibility & & & & & & \\
\hline $\begin{array}{lll}\begin{array}{l}\text { Concerns } \\
\text { use/misuse }\end{array} & \text { about employee } \\
\end{array}$ & & & & & & \\
\hline Work culture and perceptions & & & & & & \\
\hline
\end{tabular}

6. What is your state doing to mitigate concerns and risks of using social media? Select all that apply
a. Negotiating custom agreements with providers
b. Developing/implementing policies
c. Developing/implementing guidelines
d. Monitoring use
e. Registering users
f. Requiring secure sign-in
g. Educating users
h. Selectively blocking users
i. Do not have any concerns

7. Despite foregoing risks and concerns, how would you characterize the current status or implementation of social media intiatives in your state?

a. Full speed ahead - tools are critical elements of strategic vision for 21st century government

b. Proceeding with caution - tools have their place but much is unknown

c. Dipping toes in water - trying to better understand place of tools

d. Doing very little - have other priorities 
8. What steps has your state or the $\mathrm{ClO}$ office taken to encourage use of your social media sites by citizens, employees, or other communities of interest? Select all that apply
a. Web marketing
b. Word of mouth
c. Public service announcements (print, radio, TV)
d. Public presentations
e. Media relations
f. Metrics and analytics
g. Social media aggregatiob on web portal
h. Contest, promotions and giveaways
i. Cross-promotion with other communication channels
j. Feedback surveys/polling
k. Mobile apps
I. Not applicable - not encouraging greater use

Personnel

Please circle one choice for each of the following statements

( 1 =strongly disagree, $2=$ disagree, $3=$ nor disagree nor agree, 4 = agree, $5=$ strongly agree, $\mathrm{X}=$ do not know

\begin{tabular}{|l|l|l|l|l|l|l|l|}
\hline & \multicolumn{1}{|l|}{} & & & & \\
\hline 1 & $\begin{array}{l}\text { Public officials in our organizations are an extremely } \\
\text { important source of information }\end{array}$ & & & 4 & 5 & X \\
\hline 2 & Information from social media network is very important & & & & & & \\
\hline 3 & $\begin{array}{l}\text { Our public officials have high competence in handling social } \\
\text { media }\end{array}$ & & & & & \\
\hline 4 & $\begin{array}{l}\text { Our organization has a high level of technical expertise in- } \\
\text { house }\end{array}$ & & & & & \\
\hline 5 & $\begin{array}{l}\text { Our organization has technical level of senior information } \\
\text { team }\end{array}$ & & & & & \\
\hline 6 & $\begin{array}{l}\text { In our organization we explitly reward public servant that a } \\
\text { source of quality informaiton from social media }\end{array}$ & & & & & \\
\hline 7 & $\begin{array}{l}\text { In our organization we often organize internal training on } \\
\text { social media use }\end{array}$ & & & & \\
\hline
\end{tabular}

Structure and Position

\begin{tabular}{|l|l|l|l|l|l|l|l|}
\hline & \multicolumn{1}{|l|}{} & 1 & 2 & 3 & 4 & 5 & $\mathrm{X}$ \\
\hline 1 & $\begin{array}{l}\text { Information from social media allows for efficient and } \\
\text { effective exchange of information within the organization }\end{array}$ & & & & & \\
\hline 2 & $\begin{array}{l}\text { All member of our organization are aware what the goals of } \\
\text { the social media use }\end{array}$ & & & & & \\
\hline 3 & $\begin{array}{l}\text { We frequently hold meeting with the purpose to inform the } \\
\text { follow up of information from social media }\end{array}$ & & & & & \\
\hline 4 & $\begin{array}{l}\text { We have formal mechanism and system that ensure tranfer } \\
\text { of best practices among various agencies }\end{array}$ & & & & & \\
\hline 5 & Communication amongts units is easy to do & & & & & & \\
\hline 6 & Organizational hierarchy is not problem & & & & & \\
\hline 7 & Every unit could communicate each other without border & & & & & \\
\hline 8 & & & &
\end{tabular}

Communication and Information

\begin{tabular}{|l|l|l|l|l|l|l|l|}
\hline 1 & $\begin{array}{l}\text { In our organization we have public servant that work in } \\
\text { more than one team or project groups together with public } \\
\text { servants from other agency unit }\end{array}$ & & 2 & 3 & 4 & 5 & X \\
\hline 2 & In our organization we have virtual coordination & & & & & & \\
\hline 3 & $\begin{array}{l}\text { In our organization we have one agency to integrate } \\
\text { informations from social media }\end{array}$ & & & & & \\
\hline 4 & $\begin{array}{l}\text { It is very easy job to coordinate among those agencies to } \\
\text { solve problem from social media }\end{array}$ & & & & \\
\hline
\end{tabular}

(continued) 


\begin{tabular}{|l|l|l|l|l|l|l|l|}
\hline 5 & $\begin{array}{l}\text { We have frequently meeting among agencies to share } \\
\text { information }\end{array}$ & & & & & \\
\hline 6 & $\begin{array}{l}\text { Good quality of content in social media in term of accuracy } \\
\text { and field based information }\end{array}$ & & & & & \\
\hline 7 & & & & & & & \\
\hline
\end{tabular}

\section{2}

Organization Culture and Cognitive Routine

Indicate the degree of change that best approximates the actual developments in your city organization after using social media?

( 1 = substantial decline/decrease, 2 = moderate decline $/$ decrease, $3=$ no change, $4=$ moderate improvement/increase, 5 = substantial improvement/increase

\begin{tabular}{|c|c|c|c|c|c|c|c|}
\hline & & 1 & 2 & 3 & 4 & 5 & $x$ \\
\hline 1 & Adaptability of public demands & & & & & & \\
\hline 2 & Quality of public services & & & & & & \\
\hline 3 & Number of public services offered & & & & & & \\
\hline 4 & Speed of public service operation & & & & & & \\
\hline 5 & Introduction of new public service approach & & & & & & \\
\hline 6 & Average productivity of public servants & & & & & & \\
\hline 7 & Satisfaction of public servants & & & & & & \\
\hline 8 & Overall atmosphere & & & & & & \\
\hline 9 & $\begin{array}{l}\text { Personal communication netween top management and } \\
\text { the their subordinates }\end{array}$ & & & & & & \\
\hline 10 & Meeting effeciently & & & & & & \\
\hline 11 & $\begin{array}{l}\text { Public officials's level of understanding of major problems of } \\
\text { the city }\end{array}$ & & & & & & \\
\hline 12 & $\begin{array}{l}\text { Public officials's level of understanding of city's strategic } \\
\text { orientation }\end{array}$ & & & & & & \\
\hline
\end{tabular}

\section{Public Policy Making}

Service (Technical Innovations)

\begin{tabular}{|l|l|l|l|l|l|l|l|}
\hline & \multicolumn{1}{|l|}{} & 1 & 2 & 3 & 4 & 5 & X \\
\hline 1 & $\begin{array}{l}\text { In our organization, social media information is very } \\
\text { important for policy input }\end{array}$ & & & & & \\
\hline 2 & We interpret information from social media fastly & & & & & & \\
\hline 3 & We always prioritize information from social media & & & & & & \\
\hline 4 & $\begin{array}{l}\text { Our top management always prioritize to solve problem } \\
\text { based on social media information }\end{array}$ & & & & & \\
\hline 5 & $\begin{array}{l}\text { Compare with web, social media is very effective way to } \\
\text { make public policy }\end{array}$ & & & & \\
\hline
\end{tabular}

Process Innovations

\begin{tabular}{|l|l|l|l|l|l|l|l|}
\hline & \multicolumn{1}{|l|}{} & 1 & 2 & 3 & 4 & 5 & X \\
\hline 1 & Social media use develop the new channels for public policy & & & & & & \\
\hline 2 & We deal with public demands and complaints urgently & & & & & & \\
\hline 3 & We deal with public demands fastly & & & & & & \\
\hline 4 & $\begin{array}{l}\text { After using social media we do not need to make decision in } \\
\text { long process }\end{array}$ & & & & & \\
\hline 5 & Speed policy making & & & & & & \\
\hline 6 & Open public policy making process & & & & & \\
\hline
\end{tabular}




\begin{tabular}{ll}
\hline Issue & Questions to be raised and answered \\
\hline $\begin{array}{l}\text { Objectives and } \\
\text { expectations }\end{array}$ & What is the core mission of my institution? \\
& What are the most important information and services provided by my institution? \\
& How important is public communication for achieving my institution's core \\
& objectives? \\
& How can social media support my institution's core mission? What are examples from \\
& Can social media enable outside actors to support selected activities of my institution, \\
& e.g. intermediaries or individuals for which my institution can provide a platform for \\
collaboration?
\end{tabular}

Governance modes Is there a central oversight body for social media use across government or is the and guidelines

Legal compliance

Skill and resources

Collaboration and
community-building

Managing risks of
social media use

Monitoring and measuring social media impacts preferred operating mode one of dispersed innovation?

How can different organizational units in my institution leverage social media, e.g. the public relations department, the IT department, the policy making department and the service delivery department?

Is there a need for social media guidelines for civil servants, including for personal use?

Is there a need for social media guidelines for official institutional accounts, e.g.

Facebook presence of a given ministry?

Who, if anybody, sets guidelines for social media use by politicians or appointed

high-ranking civil servants representing an institution?

What are the specific legal and regulatory provisions that may have an impact on how my institution uses social media?

Are social media covered or excluded from official record-keeping?

What disclaimers should be added to the social media presence?

What information is my institution allowed to re-use when it comes to privacy

protection or compliance with intellectual property laws?

How to ensure that my institution's social media use meets requirements for accessibility of information and services?

What human resources are available or can be mobilized to achieve sustainable impacts?

Are social media skills addressed by wider (digital)skills strategies at my institution or government?

How are social media expenses accounted for? Can they be extracted from overall communications expenses to calculate specific costs?

Do government communities exist where I can exchange social media experiences?

What coordination or collaboration mechanisms would help my institution understand and maximize the impact of social media?

How damaging would reputational risks be for my institution?

Does my institution need to worry about unintentional disclosure of information?

What share of civil servants uses social media in their personal capacity?

Are social media risks addressed by overarching strategies for managing risks in my institution or government?

How advanced are my social media indicators? What do they actually measure: presence, popularity, penetration, perception or purpose?

Does my institution use indicators that evaluate the contribution to actual core objectives?

What would be an ideal set of metrics for my institution's use of social media?

What information sources can I use to move from the current metrics to an ideal set of purpose-oriented indicators?

Table AI. Quide interview 


\section{Information factors}

(1) Communications

- Community outreach (emergency, crime/traffic alerts, 24/7 level of service, recruitment).

- Feedback (from community to organization, social trends, locale, fast spreading ideas).

- Population reached (misses traditional/older population or can't afford technology).

- One-way vs two-way (pushing out vs creating dialogue, effort/costs different).

- Tone (Government presents just the facts, not stories, not press release, listen then educate).

(2) Information

- Quality of content (accuracy, facts of situation, un-vetted information, misinformation).

- Quantity of messages (how to be heard, from 1 to 10 to 1000s, overwhelming, loss of control).

- Personal level (information overload, ability to write complete thoughts, nuances of face-to-face lost).

(3) Technology

- Security (network exposed to world).

- Technology and equipment (cost of technology and maintenance, cost savings, training).

- Social media (SM) outlets (knowing audience/expertise, users expect transparency, so many outlets).

- Public record/FOIA (are SM public record, tools needed to save, outdated polices).

\section{Organization factors}

(1) Policy

- Management buy-in (unknown expectations, undervalued, need to set culture).

- Control issues (how much to control, what we can control, telling how/what to think/do).

- Human resource (HR) components (job descriptions, evaluation, expertise, dialogue, positive and negative).

- SM communications policy (what not to do/say, right people to make SOP, moving target).

- Professional level (privacy concerns, devices owned by county, investigative purposes).

(2) Legal issues

- Data maintenance (FOIA data maintenance and related costs).

- Owing vs using someone else (official outlet versus imposter, use in investigations.

- Public record/FOIA (are SM public record, tools needed to save, outdated polices).

- Costs. 
- Resource issues (SM adds to previously full-time job, other duties, limit 24/7 expectation).

- $\mathrm{ROI} / \mathrm{cost}$ to value (how to measure value, who are we reaching, enough received messages).

- Training.

- Education (tools to manage, learning from each other, train constituents where to go).

- Training (best practices for dividing duties, case studies, understanding management's concerns).

- Other (educate nonusers, establish boundaries).

S-government measurement

(1) Activity metrics

- Bounce rate.

- Brand mentions.

- Comments and trackbacks.

- Connections (between members).

- Contributors.

- Interactivity (with other media).

- Loyalty.

- Members, friends, followers.

- Number of groups (networks/forums).

- Page views.

- Posts (ideas/threads).

- Referrals.

- Tags/ratings/rankings.

- Time spent on site.

- Virility - spread of posts Visitors/unique visitors.

(2) Activity ratios

- Frequency: visits, posts, comments by time period.

- Ratios: member to contributor; posts to comments; active to passive contributors, etc.

(3) Customer service metrics

- Quality and speed of issue resolution.

- Relevance of content, connections.

- Satisfaction

(4) ROI measurements

- Cost per lead.

- Cost per prospect.

- Lead conversion.

- Lifetime value of customers.

- Number of leads per period. 
TG

11,3

376

- Number of new product ideas.

- Number of qualified leads per period.

- Ratio of qualified to non-qualified leads.

- Time to qualified lead.

(5) Results

- Number of mentions (tracked via web or blog search engines).

- Positive/negative listing ratios on major search engines.

- Positive/negative sentiment in mentions.

\section{About the authors}

Sataporn Roengtam is a Professor at the Department of Public Administration, Khon Kaen University, Thailand. His research interests are local governance and democracy.

Achmad Nurmandi is a Director of Jusuf Kalla School of Government, Universitas Muhammadiyah Yogyakarta, Indonesia. His research interest is strategic management in public sector, urban governance and e-government. Achmad Nurmandi is the corresponding author and can be contacted at: nurmandi_achmad@umy.ac.id

David N. AlMarez's research interest is e-government and democracy.

Anwar Kholid's research interest is e-government and government reform.

For instructions on how to order reprints of this article, please visit our website: www.emeraldgrouppublishing.com/licensing/reprints.htm

Or contact us for further details: permissions@emeraldinsight.com 